\title{
A STUDY TO ASSESS THE EFFECTIVENESS OF STP ON KNOWLEDGE REGARDING BREAST ENGORGEMENT AND ITS MANAGEMENT, AMONGPRIMIPARA UNDERGONE LOWER SEGMENT CAESAREAN SECTION (LSCS) ADMITTED IN SELECTED GOVT. HOSPITAL AT JAIPUR
}

\author{
ARCHANA $^{1}$,BLESSY VARGHESE ${ }^{2}$ \\ ${ }^{1}$ Assistent Professior Rajasthan College of Nursing,Jaipur Rajasthan \\ ${ }^{2}$ Asso.Professor cum HOD of OBG Nursing, Jaipur Hosital Colege oF Nursing,Rajasthan
}

Corresponding Email: archanakmwt@,gmail.com

\begin{abstract}
Introduction: Early identification of symptoms of breast engorgement may help to prevent further complication in the breast. education towards initiation of breast feeding. Feeding in correct position and avoidance of prelacteal feeds creates awareness to avoid the occurrence of breast engorgement. Manual expression of milk, supporting the breast with binder, breast massage, putting the baby to the breast regularly and administration of analgesics will help to reduce the breast engorgement'
\end{abstract}

Material and Method: This study was conducted inGov.hospital Jaipur Rajasthan.Sample size in this study was 60 primipara undergone LSCS. A quasi-experimental design with one group pre-test and post-test was used toassess the effectiveness of the structured teaching programmed for the present study.

Result:The present study findings showed a highly significant difference between mean pretest $\left(\mathrm{X}_{1}=13.3\right)$ and post-test $\left(\mathrm{X}_{2}=19.2\right)$ knowledge scores.In breast feeding with the maximum score of $66.11 \%$, In diagnosis and management of breast engorgement with maximum score of $61.66 \%$ diagnosis and management of breast engorgement with maximum score $60.45 \%$.

Conclusion-.it is concluded that the level of knowledge regarding breast engorgement and its management among primipara undergone LSCS admitted in selected Govt. hospital at Jaipurits was inadequate.

Keyword:Effectiveness, Primipara, Caesarean Section

\begin{tabular}{ccc}
\hline Received & Accepted & Available online \\
\hline $25 / 08 / 2021$ & $08 / 09 / 2021$ & $03 / 10 / 2021$ \\
\hline
\end{tabular}




\section{INTRODUCTION}

\section{Motherhood is... difficult and...}

\section{Rewarding."- Gloria Estafan}

Mother is placed at the level of God to provide love, warmth and satisfy needs of baby. The birth of a baby is an important event in any family. It is therefore important for the mothers to have a healthy baby. Breast milk is the best food for the babies as breastfed babies are healthier than formula fed babies. Caesarean section is a method of delivering baby through an incision made in the mother's lower abdominal wall and uterus instead of delivery through the Vagina.The National Family Health Survey (NFHS) has indicated that painful breast is the second most common reason for giving up breast feeding in the two weeks after birth in India. Breast engorgement occurs in $72 \%$ to $85 \%$ of women and commonly occurs within 3 to 6 days after delivery. An engorged breast is enlarged, swollen and painful. It may be shiny and edematous with diffuse red areas. The nipple may be stretched flat. The milk often does not flow easily, and it may be difficult for the infant to attach the breast for suckle until the swelling is reduced. Breast engorgement can occur anytime during lactation when milk is not transferred from the breast.

\section{MATERIAL AND METHOD-}

An experimental approach with quasiexperimental one group pre-test post-test design was used for this study. The study was carried out in selected Govt. hospital at Jaipur. The sample comprised of 60primipara undergone LSCS who met the inclusion criteria and were chosen by purposive sampling technique.

The following section was adopted to develop the STP.

\section{SECTION 1:}

$>$ Description of socio-demographic characteristics of participants

\section{SECTION 2:}

$>$ Percentage distribution On level of knowledge and knowledge in specific areas related to breast engorgement and its management among primipara undergone LSCS

Mean percentage \& standard deviation of pre-test knowledge scores

$>$ Mean, mean percentage and standard deviation of post- test knowledge scores

$>$ Frequency and Percentage distribution on pre test and post test level of knowledge of primipara

\section{$\underline{\text { SECTION } 3}$}

Effectiveness of structured teaching programme on breast engorgement 


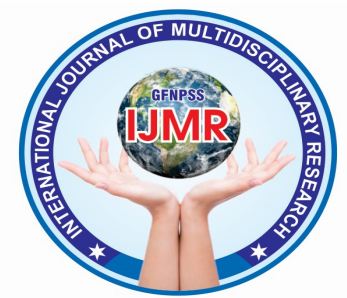

and its management by comparing area wise pre and post -test knowledge scores of primipara undergone LSCS

Significance difference between overall pre-test and post- test knowledge scores.

\section{SECTION 4}

$>$ Association between the pre- test knowledge score of primipara on breast engorgement and its management with selected sociodemographic variables

\section{RESULT:}

\section{DISTRIBUTION OF DEMOGRAPHIC}

\section{VARIABLES}

The following conclusions were drawn on the basis of the findings of the study show below in table.

$>$ The pre-test knowledge scores among most of the primipara were poor and average.

$>$ The introduction of the STP among the primipara helped them to learn more about breast engorgement and its management, which was evident, in the post-test knowledge scores.

\begin{tabular}{|l|l|c|l|}
\hline $\begin{array}{l}\text { S. } \\
\text { No. }\end{array}$ & Variables & Frequency & $\begin{array}{l}\text { Frequency } \\
\text { Percentage }\end{array}$ \\
\hline $\mathbf{1}$ & Age in Years & & \\
& $18-22$ & 19 & $31.66 \%$ \\
& $22-26$ & 22 & $36.66 \%$ \\
& $26-30$ & 16 & $26.66 \%$ \\
& Above 30 & 3 & $5 \%$ \\
\hline $\mathbf{2}$ & Family Type & & \\
& Joint & 32 & $53.33 \%$ \\
& Nuclear & 28 & $46.66 \%$ \\
\hline
\end{tabular}

\section{SECTION - I DESCRIPTION OF} SOCIO-DEMOGRAPHIC CHARACTERISTICS OF PARTICIPANTS

Table 1 Frequency and percentage distribution of demographical variables of primipara undergone $\operatorname{LSCS} \mathbf{N}=\mathbf{6 0}$

method of information It was well appreciated and accepted by the primipara.

The chances for the better practice in breast engorgement and its management could be anticipated a variety of other information on breast engorgement and its management.$$
\text { primipara undergone LSCS } \mathbf{N}=\mathbf{6 0}
$$

\footnotetext{
The STP proved its validity as one of the effective teaching
} 


\begin{tabular}{|c|c|c|c|}
\hline 3 & $\begin{array}{l}\text { Education Level } \\
\text { Secondary } \\
\text { Sr. Secondary } \\
\text { Graduate } \\
\text { Post Graduate }\end{array}$ & $\begin{array}{c}9 \\
19 \\
26 \\
6\end{array}$ & $\begin{array}{l}15 \% \\
31.66 \% \\
43.33 \% \\
10 \%\end{array}$ \\
\hline 4 & $\begin{array}{l}\text { Family Income } \\
\text { Less than } \\
\text { Rs. } 10000 \\
\text { Rs. } 10001 \text { - } \\
\text { Rs. } 30000 \\
\text { Rs. } 30001 \text { - } \\
\text { Rs. } 40000 \\
\text { Above Rs. } 40000\end{array}$ & $\begin{array}{l}10 \\
20 \\
18 \\
12\end{array}$ & $\begin{array}{l}16.66 \% \\
33.33 \% \\
30 \% \\
20 \%\end{array}$ \\
\hline 5 & $\begin{array}{l}\text { Occupational } \\
\text { status } \\
\text { Private employee } \\
\text { Housewife } \\
\text { Govt. Employee } \\
\text { Business }\end{array}$ & $\begin{array}{l}19 \\
22 \\
16 \\
03\end{array}$ & $\begin{array}{l}31.66 \% \\
36.66 \% \\
26.66 \% \\
5 \%\end{array}$ \\
\hline 6 & $\begin{array}{l}\text { Previous } \\
\text { Knowledge } \\
\text { Yes } \\
\text { No }\end{array}$ & $\begin{array}{l}16 \\
44\end{array}$ & $\begin{array}{l}26.66 \% \\
73.33 \%\end{array}$ \\
\hline 7 & $\begin{array}{l}\text { Source of } \\
\text { Knowledge } \\
\text { Family members } \\
\text { Health Personnel } \\
\text { Mass media } \\
\text { Friends }\end{array}$ & $\begin{array}{l}8 \\
3 \\
2 \\
3\end{array}$ & $\begin{array}{c}50 \% \\
18.75 \% \\
12.5 \% \\
18.75 \%\end{array}$ \\
\hline
\end{tabular}

participants belong of Joint family, $46.66 \%$ (28) of lived in Nuclear family.

On the bases of Education level, 15\% (9) participants Secondary educated, 31.66\% (19) were $\mathrm{Sr}$. Secondary educated, $43.33 \%$ (26) participants were Graduates and rest10\% (6) were Post Graduates.

Family income wise, $16.66 \%$ (10) participants were distributed in lessthanRs.10000 monthly income, $33.33 \%$ (20) were distributed in Rs.10001 - Rs.30000, 30\% (18) were distributed in Rs.30001 Rs. 40000 , rest of $20 \%$ (12) have a family income of more than Rs.40000 pm.

Table 1 shows the distribution of the socio demographic variables.

Age wise data shows, those $31.66 \%$ (19) participants were distributed in 18-22 years of age, $36.66 \%$ (22) were distributed in 22-26 years, $26.66 \%$ (16) were distributed in 26-30 years, and 5\%

(3) were above 30 years of age.

$>$ The data based on Family Type, shows that $53.33 \%$ (32) of

On the bases of Occupational status, were $36.66 \%$ (22)of participants were Homemaker, $31.66 \%$ (19) were participants were Private Employees, 26.66\% (16) were Govt. Employees ,as 5\% (3) were Business Women

On the basis of previous knowledge regarding breast engorgement and its management., $26.66 \%$ participants were 


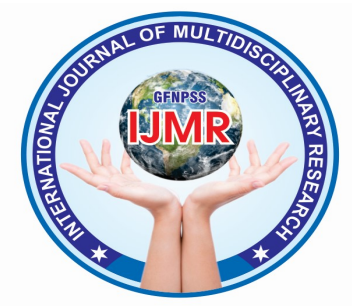

answered 'Yes', instead the rest $\mathrm{N}=60$ $73.33 \%$ (44) answered as 'No'

The ones answered as 'Yes', were asked for the source of their knowledge. $50 \% \quad(8)$ answered 'Family Members', $18.75 \%$ answered 'Health Personnel', 12.5\% (2) answered 'Mass Media', and the rest $18.75 \%$ (3) answered 'Friends'.

Table 2. Frequency and Percentage distribution on pre test post test level of knowledge of primipara $N=60$

\begin{tabular}{|c|c|c|c|c|c|c|}
\hline \multirow[t]{2}{*}{ S.NO } & \multirow{2}{*}{$\begin{array}{l}\text { Level of } \\
\text { Knowled } \\
\text { ge }\end{array}$} & \multirow{2}{*}{$\begin{array}{l}\% \text { of } \\
\text { score }\end{array}$} & \multicolumn{2}{|l|}{$\begin{array}{l}\text { Pre } \\
\text { test }\end{array}$} & \multicolumn{2}{|l|}{$\begin{array}{l}\text { Post } \\
\text { test }\end{array}$} \\
\hline & & & $\begin{array}{l}\text { Frequ } \\
\text { ency }\end{array}$ & $\begin{array}{c}\text { Freq } \\
\text { uency } \\
\%\end{array}$ & $\begin{array}{l}\text { Freq } \\
\text { uenc } \\
y\end{array}$ & $\begin{array}{l}\text { Frequ } \\
\text { ency } \\
\%\end{array}$ \\
\hline 1. & Poor & $0-49$ & 15 & 25 & 0 & $\mathbf{0}$ \\
\hline 2 & Average & 50-74 & 27 & 45 & 21 & 35 \\
\hline 3. & Good & $\begin{array}{l}75 \text { or } \\
\text { above }\end{array}$ & 18 & 30 & 39 & 65 \\
\hline
\end{tabular}

The data of table no. 2 shows that in pre test majority of primipara $45 \%$ (27) had average knowledge and 30\% (18) had good knowledge about the topic, and $25 \%(15)$ had poor knowledge .

Table 3: Significance difference between overall pre-test and post-test knowledge scores

\begin{tabular}{|l|l|l|l|l|l|l|l|l|}
\hline $\begin{array}{l}\text { S. } \\
\text { No }\end{array}$ & Score & & & & & & \multicolumn{2}{|l|}{} \\
\hline & & $\begin{array}{l}\text { Mea } \\
\mathbf{n}\end{array}$ & S.D & $\begin{array}{l}\text { Std. } \\
\text { erro } \\
\text { r }\end{array}$ & $\begin{array}{l}\text { Mean } \\
\text { differe } \\
\text { nce }\end{array}$ & $\begin{array}{l}\text { D. } \\
\text { F }\end{array}$ & \multicolumn{2}{|l|}{ 't' table } \\
\cline { 3 - 8 } & & $\begin{array}{l}\text { Calculat } \\
\text { ed value }\end{array}$ & $\begin{array}{l}\text { Tabula } \\
\text { ted } \\
\text { value }\end{array}$ \\
\hline 1 & $\begin{array}{l}\text { Pre- } \\
\text { test }\end{array}$ & $\begin{array}{l}13.3 \\
0\end{array}$ & $\begin{array}{l}8.7 \\
1\end{array}$ & 0.98 & 5.96 & 5 & 20.78 & 2 \\
\hline 2 & $\begin{array}{l}\text { Post- } \\
\text { test }\end{array}$ & $\begin{array}{l}19.2 \\
6\end{array}$ & $\begin{array}{l}9.8 \\
2\end{array}$ & & & 9 & & \\
\hline
\end{tabular}

Table: 3 describe the comparison of pretest and post-test knowledge scores. The tabulated value is less than the calculated' value (20.78) which represents the significant gain in knowledge of ' $t$ ' score at $5 \%$ degree level of significance and 59 degrees of freedom is 2 and the table value was less than the calculated value.

DISCUSSION: The present study was conducted to assess the effectiveness of structured teaching programme among the primipara undergone LSCS of selected Govt. hospitals at Jaipur. The quasi experimental deigns with (one group pre and post ) method was found appropriate to achieve the stated goals among 60 participants at selected Govt. hospitals at Jaipur. 


\section{CONCLUSION:}

From the findings of the present study, it is concluded that the level of knowledge regarding breast engorgement \& its management among primipara undergone lower segment caesarean section (lscs) admitted in selected govt. hospital at jaipur." can be further improved by providing structured teaching programme.

\section{REFERENCES:}

1. en.wikipedia.org/wiki/women's health

2. Project coordinator, district level, household and facility survey-3, international institute for population sciences 2007-2008,(citedon10th Oct 2012).www.rchiips.org, access on

3. Basavanthappa B T. Essentials of Midwifery and Obstetrical Nursing. $1^{\text {st }}$ edition. Newdelhi: Jaypee Publishers; 2011.P.344-345.

4. Stephanie Schulz neurohr et al. The breast feeding task force of greater los angeles. Media , community, health care government.California.2008.) 